\title{
液体窒素の沸騰を利用したノズル噴流の加速性能向上に関する研究
}

\section{Study on Improvement Acceleration Performance of Jet from Nozzle by use of Boiling of Liquid Nitrogen}

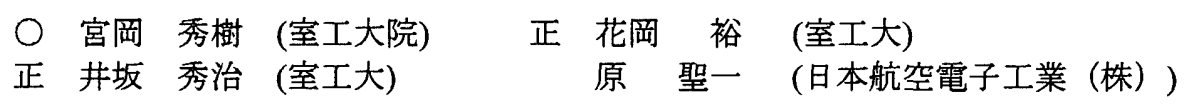

\begin{abstract}
Hideki MIYAOKA, Yutaka HANAOKA, Hideharu ISAKA,
Dept. of Mech.Engng., Muroran Institute of Technology,Mizumoto-cho 27-1,Muroran, Hokkaido Seiichi HARA, Japan Aviation Electronics Ind,Ltd.,1-21-1,Dogenzaka,Shibuya-ku,Tokyo
\end{abstract}

Key Words: Liquid Nitrogen, Acceleration of Water, Two-Phase Flow, Convergent-Divergent Nozzle

\section{1. 蟙䡒}

水中での推力を得るためには, スクリューなどの駆動装置 が必要となり, 機構が複雑になる，そこで，より単純に推力 を得る方法として, 低沸点液体が常温で液体から気体へ変化 する性質に着目した。すなわち，低沸点液体の沸騰による体 積膨張を利用してノズル内の水を押し出すことにより推力 を得る方法である．注入媒体としては液体窒素（以下 $\mathrm{LN}_{2}$ と称す）を用いた。

本報告では, $\mathrm{LN}_{2}$ の沸騰膨張を利用したノズル噴流の加速 性能が，諸条件下でどのような影響を受けるか，推力測定お よび壁面静圧測定から検討した。

\section{2. 实験策馈および实験方法}

実験装置には， 2 種類の先細末広ノズル（Nozzle-A：挔が り角 5 度, Nozzle-B: 拡がり角 8 度) を使用し，その後方に, $\mathrm{LN}_{2}$ と水の直接接触時間を増やし，より完全な沸騰を起こさ せるために着脱可能なパラレルパイプを設置する. 推力は噴 流の反力を測定して用いた。実験は，水をポンプによりノズ ル内へ送り込み, $\mathrm{LN}_{2}$ をそのズルのど部より流れ方向に注 入することにより， $\mathrm{LN}_{2}$ が沸騰し水と窒素ガスの二成分気液 二相流となり水槽内に噴出されることによって行われる.

\section{3. 実䀦結果および考察}

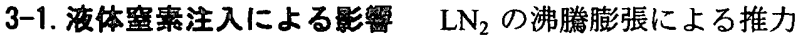
への影響を調べるために，ノズルへの供給以前から完全に気 化していたと想定し空気を注入した場合に得られる推力と の比較を試みた結果を Fig.1 に示す. 図より $\mathrm{LN}_{2}$ 注入時の方 が推力が大きかった.これは，ノズル内で $\mathrm{LN}_{2}$ が沸騰し窒素 ガスとなることにより体積が約 700 倍になり,その結果,気液 二相流は加速噴流となって装置外部一排出され大きな推力 につながった.

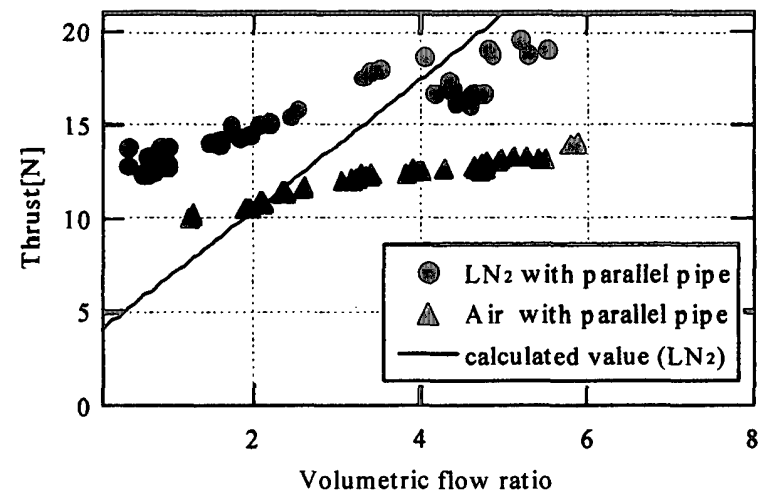

Fig.1 Relationship between thrust and volumetric flow ratio (Nozzle-A, injected liquid Nitrogen or Air)

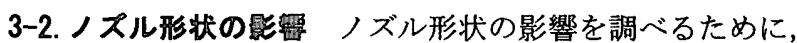
パラレルパイプ非装着で各々のノズルを使用し推力を比較 した. その結果, Nozzle-A の方が推力が大きかった. ところ で, Nozzle-A は全長が長いことで壁面摩擦を含め流動抵抗が 大きいにも関わらず全長の短い Nozzle-B よりも推力が大き い.このことから,ノズル内では流動抵抗以外の加速性に奇 与する何らかの要因が流路内にあると考えられる.そこで, ノズル内の壁面静圧測定を行った結果, Nozzle-A ではノズル 出口に向かうにしたがい圧力低下する擬似的な気液二相超 臨界状態の圧縮性流体の特性を示した。逆に Nozzle-B では ノズル出ロに向かうにしたがい圧力回復する亜音速状態の 非圧縮性流体の特性を示した. なお, 円形断面における拡が り損失は，単相においては拡がり角 5 度で最小となることが 知られていることから (1), Nozzle-A の拡がり角が適している と考えられる.したがって，ノズル形状の違いにより内部流 れが変化し, 結果的に Nozzle-A の方が推力が大きくなった と考えられる.

3-3. パラレルパイプの有释による影整 パラレルパイプ装 着による推力への影響を調べるために, パラレルパイプ装着 時と非装着時の推力を比較した. その結果, 推力に大きな差 はなかった. むしろ, パラレルパイプ装着時の推力がやや抑 制される傾向が認められた.これは, パラレルパイプ内の沸 腾気泡が噴流の流動抵抗になっていると考えられる.このこ とを確認するために，空気を注入した場合のパラレルパイプ 装着の有無による推力の測定を行った. 空気注入時でもパラ レルパイプ装着の推力は低下した. 空気注入時は沸騰などの 急激な相変化は起こらないので,この推力低下は, 沸腾区間 として設けたパラレルパイプが噴流に対する流動抵抗に なっていると考えられる. また, パラレルパイプ非装着の場 合, $\mathrm{LN}_{2}$ 注入時に流量比を增大させていくと推力のばらつき が大きくなった. これは, $\mathrm{LN}_{2}$ が充分な沸騰を起こす前に水 槽へ排出されたためと考えられる. したがって, パラレルパ イプは充分な沸騰を起こすための沸騰区間として機能し, 推 力を安定に得るために効果があることがいえる.

4. 結霄

本実験の結果, $\mathrm{LN}_{2}$ 注入による沸騰・膨張の効果として噴 流の加速性がみられた. また，ノズルの搪がり角の違いによ りノズル内部の流れは変化し, 推力に大きな影響をおよほす ことが明らかとなった.さらに，沸騰区間として設けたパラ レルパイプは $\mathrm{LN}_{2}$ の沸騰を充分に起こさせ, 推力を安定的に 得る効果があった

参考文献(1)中山泰喜, 流体の力学, 養賢堂, (1994), ppl11. (2)原聖一，機講論, 40 No.309.(2000-9),pp112-113. 